Meta

Journal des traducteurs

Translators' Journal

\title{
In Memoriam - Adiós to Gregory Rabassa, Translator Extraordinaire
}

\section{María Constanza Guzmán}

Volume 61, numéro 2, août 2016

URI : https://id.erudit.org/iderudit/1037757ar

DOI : https://doi.org/10.7202/1037757ar

Aller au sommaire du numéro

Éditeur(s)

Les Presses de l’Université de Montréal

ISSN

0026-0452 (imprimé)

1492-1421 (numérique)

Découvrir la revue

Citer ce document

Guzmán, M. C. (2016). In Memoriam - Adiós to Gregory Rabassa, Translator

Extraordinaire. Meta, 61(2), 251-251. https://doi.org/10.7202/1037757ar d'utilisation que vous pouvez consulter en ligne.

https://apropos.erudit.org/fr/usagers/politique-dutilisation/ 


\section{In Memoriam Adiós to Gregory Rabassa, Translator Extraordinaire}

June saw the passing of internationally renowned translator Gregory Rabassa. He translated over fifty novels from Spanish and Portuguese by both established and emerging writers, most memorably Julio Cortázar and Gabriel García Márquez. Rabassa's translations became established as part of the Latin American literary canon; he translated key works of what came to be known as the Latin American Boom.

Born in 1922 in Yonkers, New York, Rabassa was drawn to languages from an early age. The son of a New Yorker and a Cuban sugar broker, he was raised in a multilingual and multicultural environment. His first book-length translation was Cortázar's Rayuela; with Hopscotch (1966) he won the first National Book Award for Translation in the United States in 1967. This translation led him to One Hundred Years of Solitude, by García Márquez, an author then little known internationally who subsequently became Colombia's first Nobel Laureate.

A professor and a scholar, Rabassa taught for years at Queens College in New York and wrote widely about literature and translation practice. In 2005 he published If This Be Treason: Translation and Its Dyscontents, his "translator's memoir." In it he described his life-long translation path and his camaraderie with several of the authors whose works he translated. Among the remarkable aspects of Rabassa's character that transpires in his writings are his love of language and literature, his humility, his humour and wit, and his rare generosity.

In addition to supporting authors by translating their works, Rabassa was a teacher and a beloved mentor to generations of translators, writers, and critics. I had the pleasure of meeting Rabassa for an interview in $2005 .^{2} \mathrm{He}$ was an exceptional conversationalist and his striking intellect and erudition were awe-inspiring.

Gregory Rabassa will always be remembered and generations to come will continue to have the fortune to enjoy his masterful work.

María Constanza Guzmán York University, Toronto, Canada

\section{NOTES}

1. Rabassa, Gregory (2005): If This Be Treason: Translation and Its Dyscontents. A Memoir. New York: New Directions.

2. Published in Constanza Guzmán, María (2011): Gregory Rabassa's Latin American Literature: A Translator's Visible Legacy. Lewisburg: Bucknell University Press. 